\title{
CINEMA E LITERATURA: ALGUMAS REFLEXÕES E CONSIDERAÇÕES SOBRE O ROTEIRO COMO GÊNERO INTERSEMIÓTICO
}

\author{
Ricardo André Ferreira Martins \\ Universidade Estadual do Centro-Oeste (UNICENTRO)/Irati
}

\begin{abstract}
Resumo: Este trabalho tem por objetivo realizar algumas análises e considerações a respeito das intersecções estéticas e estruturais, do ponto de vista intersemiótico, entre o roteiro e a literatura, no sentido de desenvolvimento de uma teoria do roteiro como gênero intersemiótico. Partindo dos conceitos de transposição intersemiótica, écfrasis, intertextualidade e intermidialidade, sobretudo a partir das reflexões de Claus Clüver, pretende-se, neste artigo, demonstrar a importância do roteiro para a realização da intercomunicabilidade entre o cinema e a literatura, a fim de analisar-se as fronteiras entre a arte verbal e a mídia visual.
\end{abstract}

Palavras-chave: Literatura. Cinema. Roteiro. Transposição intersemiótica.

\author{
Correspondances \\ La Nature est un temple où de vivants piliers \\ Laissent parfois sortir de confuses paroles; \\ L'homme y passe à travers des forêts de symboles \\ Qui l'observent avec des regards familiers. \\ Comme de longs échos qui de loin se confondent \\ Dans une ténébreuse et profonde unité, \\ Vaste comme la nuit et comme la clarté, \\ Les parfums, les couleurs et les sons se répondent. \\ II est des parfums frais comme des chairs d'enfants, \\ Doux comme les hautbois, verts comme les prairies, \\ - Et d'autres, corrompus, riches et triomphants, \\ Ayant l'expansion des choses infinies, \\ Comme l'ambre, le musc, le benjoin et l'encens, \\ Qui chantent les transports de l'esprit et des sens.
}

- Charles Baudelaire

A intercomunicabilidade entre os diversos gêneros artísticos tornou-se um procedimento comum nos dias de hoje. Contudo, ao mesmo tempo, é um fenômeno estético cujas 
origens se encontram em períodos muito remotos da história da arte. As famosas correspondências entre as artes foram aventadas por muitos ao longo da história, inclusive por Baudelaire, em seu célebre soneto "Les correspondences". Mas tais correspondências muitas vezes vinham encobertas por um espesso nevoeiro de falsas similitudes e diferenças verdadeiras. $\mathrm{O}$ entrelaçamento entre texto, imagem e som sempre despertou interesse ao longo da história, nas mais diversas culturas, que continuamente sentiram necessidade de transmitir suas narrativas de maneira a mais eficaz e, sobretudo, a mais memorizável possível. A articulação entre texto e música, por exemplo, é uma das mais antigas relações intersemióticas existentes, dada a antiguidade da literatura como meio artístico, que certamente teve parte de sua origem ligada aos cantos rituais sagrados ou líricos, destinados à memorização, e que bem mais tarde se transformaram em palavra escrita autônoma, mas agora sem o apoio de instrumentos musicais ou do canto. Apenas o ritmo e a sonoridade natural das palavras encadeadas, por vezes com o apoio da rima, a fim de reter o texto na lembrança. Da mesma forma, as relações entre texto e imagem estão entre as mais antigas, como o atesta Horácio em sua "Epístola aos Pisões", também conhecida como "Arte poética", através de sua famosa expressão ut pictura poesis, paradigma pictórico no qual a linguagem poética (portanto, literária) é concebida como imagem. Tal visão, sobretudo entre as literaturas neolatinas, levou, mais adiante, a considerar a imagem como manancial do próprio fenômeno poético, e, portanto, de toda a literatura. Contemporaneamente, uma atenção cada vez maior recai sobre o processo de intercomunicação de linguagens estéticas diferentes, de onde emerge um novo campo de pesquisa, característico dos estudos comparados em literatura: os estudos interartes. Com efeito, estamos falando de uma área completamente nova de investigação, na qual se realiza a observação e análise das relações existentes entre a literatura e as demais expressões artísticas (cinema, televisão, teatro, pintura, desenho, etc).

No caso dos estudos comparados de literatura, ou das "artes comparadas", um dos objetivos do pesquisador comparatista é sempre estudar como as diversas obras literárias migram ou são adaptadas para outra linguagem estética, especialmente o caso da obra cinematográfica (processo de transposição interartes de uma linguagem verbal para uma verbal e nãoverbal ao mesmo tempo, na maior parte das vezes), cuja influência sobre as demais artes tornou-se demasiado evidente para desprezá-la neste novo concerto em que o cinema fornece elementos estéticos que migram cada vez mais para a literatura, e não mais somente o contrário. Não obstante este novo campo de estudos não possuir uma teoria ou metodologia definidas, segundo Clüver (1997, p. 44) - embora se entenda o processo de transposição interartes 
como uma tradução intersemiótica da linguagem -, nele as abordagens, via de regra, ultrapassam a análise semiótica formal pura, indo ao encontro dos aspectos socioculturais do texto artístico visual ou verbal.

Com efeito, a transposição do texto literário para outras artes e outras mídias é algo corriqueiro em nossa cultura visual e verbal contemporânea. Todos os dias, textos, literários ou não, são transformados em filmes, peças teatrais, séries e novelas de televisão, propagandas, de modo que a circulação de textos através de mídias dominantemente visuais criou uma nova dieta estética, cultivada pela transformação do signo verbal em signo visual ou viceversa, cujas características mobilizam outras forças de leitura e recepção. A própria realidade dos estudos intermidiáticos e intertextuais ganhou novas dimensões a partir da expansão dos recursos fornecidos pela world wide web, a internet. A cada segundo, novos textos, visuais e verbais, ou verbivisuais, são lançados na rede internacional de troca de informações, e uma nova cultura forma-se ao redor do texto, do som e da imagem, colocados agora em novos contextos e em novas e impensadas relações. As possibilidades de relações intersemióticas aumentaram exponencialmente.

De qualquer modo, os estudos interartes são uma nova área de interesse dos estudos literários comparados, particularmente em suas relações com a teoria literária, a teoria da comunicação e a semiótica, abrindo um novo leque de possibilidades interpretativas e de pesquisa ao estudioso de literatura. Nos estudos interartes, entretanto, encontramos o termo "intermedialidade" (CLÜVER, 1997), conceito novo, ainda em construção, que encontra seus sinônimos em "intermídia" e "intermídias", cujos símiles, nos estudos literários, são noções já consagradas e conhecidas, como intertextualidade e transposição intersemiótica. Segundo Clüver (2006, p. 16), a intertextualidade e a intermedialidade apontam que um texto isolado, adaptado ou transposto a qualquer mídia ou sistema sígnico, de natureza estética ou não, constitui um expressivo objeto de pesquisa para os estudos interartes, como igualmente um texto literário isolado, em suas relações intertextuais, normalmente apresenta ao comparatista tradicional um leque muito amplo de pesquisas e estudos possíveis. Contudo, como o próprio Clüver adverte (1997), tais estudos têm que superar as fronteiras habituais dos estudos comparados, que se dedicam, na maior parte das vezes, a mais de um texto e abordam, em muitos casos, puramente a forma entre textos isolados, um texto e classes textuais, como os gêneros, ou ainda entre classes textuais existentes entre as diferentes mídias. De acordo com Clüver, o campo dos estudos interartes deve partir dos estudos das fontes, atravessando a questão da periodicidade, dos problemas de gênero e transformações temáticas, "até alcançar todas as 
formas possíveis de imitação que ocorrem através das fronteiras entre mídias (em formas técnicas estruturais, tendências estilísticas, e outras mais)" (CLÜVER, 2006, p. 16). Com isso, a abrangência dos estudos interartes alcança os aspectos transmidiáticos, em suas possibilidades e modalidades de representação, expressividade, narratividade, incluindo aí as questões de tempo e espaço em termos de recepção e representação, além da importância inegável da performance e da recitação, nas diversas artes e mídias.

Uma das questões transmidiáticas ou interartes mais candentes entre os estudiosos comparatistas é o processo de transposição intersemiótica/interartes entre a literatura e o cinema. Com efeito, para um cineasta transformar um texto literário ou um argumento inicial em roteiro de cinema, há todo um leque de questões formais que devem ser levadas em consideração, para muito além da surrada polêmica da fidelidade ao texto-fonte. Nunca é demasiado evocar a radical distinção existente entre o signo verbal e o signo visual, que, apesar de compartilharem um universo comum de referentes (uma vez que, ao fim das contas, os referentes são da ordem da natureza e os signos da ordem da cultura), possuem características formais distintas. Portanto, conduzem a formas, possibilidades e modalidades distintas de representação, expressividade e narratividade. Desse modo, indagar a respeito da "fidelidade" ou "infidelidade" de uma obra audiovisual ao texto-fonte, de natureza literária ou não, é desconsiderar que o processo de transposição intersemiótica conduz inevitavelmente à perda de uma considerável parte da expressividade do sistema sígnico (linguístico ou visual) de onde se parte, o que nos conduz ao terreno da tradução. A transposição de textos literários para outras artes e mídias (pintura, desenho, ilustração, filme, sinfonia, canção, entre outros) implica mergulhar na complexidade da representação visual de textos linguísticos, ou seja, de signos verbais para signos não-verbais, de modo que sempre se incorre na mudança de um sistema sígnico para outro. Daí se deduz uma apreciável mudança na forma de representação, considerando as modalidades adotadas no processo de transposição intersemiótica. Se entendermos a questão da linguagem como mídia (do texto-fonte para o roteiro, do roteiro para a obra audiovisual), temos um necessário transporte de um suporte físico para outro. Ora, a questão da "fidelidade" ou da "infidelidade", nesse caso, não se põe, ou não deveria se por, porque é impossível arbitrar o grau de fidelidade ou infidelidade ao longo desse processo de tradução/transposição intersemiótica, uma vez que as radicais diferenças entre os sistemas de signos nascem, necessariamente, dos diversos modos de representação que os decodificadores (leitores, roteiristas, diretores, produção técnica) têm do texto-fonte e de seu resultado final, que é a obra audiovisual (filme, televisão, teatro). Colocadas as coisas nesses termos, esta 
polêmica perde completamente seu pretenso significado, uma vez que as diferenças consideráveis entre os diversos sistemas de signos (verbais e não-verbais) já constituem interditos suficientes para as aspirações à fidelidade. O que está em jogo é o grau de perfectibilidade, e não de fidelidade, em relação ao texto-fonte, considerando que tal perfectibilidade é sempre mediada pela recepção, que conduz a uma adaptação particular, a uma leitura singular do texto-fonte, que necessariamente não corresponderá às demais possíveis. Como a mensagem é sempre mediada por um contexto, e o canal e o código não são necessariamente garantias de que a comunicação se estabeleça, inteiriça e eficaz, entre emissor e receptor, é impossível afirmar que todas as mensagens alcançarão seus destinatários da mesma forma. No caso da adaptação fílmica de uma obra literária, é necessário considerar que o roteiro é o mediador entre os dois sistemas sígnicos (o verbal e o visual), e que o próprio roteiro tem como finalidade tornar-se apenas a passagem, a rota, o mapa para a realização de uma obra audiovisual, e daí que ele seja habitualmente denominado apenas como "a forma escrita de qualquer projeto audiovisual" (COMPARATO, 1995, p. 19).

\section{Roteiro e literatura: fronteiras entre artes e mídias}

Contudo, surge uma questão: o que vem a ser um roteiro, enquanto gênero textual? Colocado muitas vezes no entrelaçamento entre o texto-fonte (a obra literária) e o produto final (a obra audiovisual, o filme), o que é este curioso objeto de escrita, cuja duração efềmera e volátil permite-nos vislumbrar a precariedade da palavra diante do texto visual? Convém aqui evocarmos o conceito de ekphrasis, de Clüver, que considera o processo de transposição intersemiótica de textos verbais para um meio artístico não-verbal:

\footnotetext{
... é uma forma de reescrita e abrange práticas como a descrição de uma estátua ou de uma catedral num livro de história da arte, a (re) criação de um concerto para piano ou de um balé em um romance, a resenha detalhada de uma ópera ou uma produção teatral, ou ainda a apresentação verbal de uma litografia no catálogo de um leilão (1997, p.44).
}

Clüver aponta este processo de "(re)criação" ou "reescrita" como o princípio fundador e fundamental do processo de transposição intersemiótica. Ao longo desse proceso, a transposição de uma obra estética verbal (literatura) para um meio artístico dominantemente não-verbal (cinema, televisão, teatro, sinfonia, pintura, ilustração, quadrinhos, etc), a obra audiovisual (no caso, o filme) empreende a tentativa de recriação ecfrástica dos procedimentos formais da obra adaptada, uma vez que seus recursos expressivos - suas modalidades de 
representação - são completamente diferentes em relação à obra original. Do mesmo modo que uma tradução entre um sistema linguístico e outro, não se realiza, com efeito, o "transporte" do texto-fonte para outro meio artístico pura e simplesmente, sem a perda de considerável parte dos recursos expressivos do meio original. O processo, na realidade, possibilita apenas uma "transposição", uma "recriação" do texto-fonte, agora submetido às coerções do sistema sígnico de chegada, que tenta, por sua vez, realizar uma adaptação, a mais perfectível possível, das coerções do sistema sígnico de partida, cujas leis são agora completamente volatizadas e diluídas.

O fato é que, apesar das aproximações possíveis entre ambas as formas de expressão artística, a linguagem textual das duas se diferencia essencialmente. A literatura, ao utilizar-se de um código simples e aberto (a escrita), permite uma infinidade de recepções as mais polissêmicas possíveis, enquanto o cinema utiliza-se de códigos e sistemas sígnicos superpostos, também abertos à polissemia, em parte herdados do teatro e da dramaturgia, sobretudo o arcabouço de cenas e diálogos, que apontam para a necessidade da representação humana. Contudo, o cinema conta com recursos físicos e tecnológicos (para não dizer técnicos) muito mais variados para a realização extrínseca de sua mensagem, que é a obra audiovisual (o filme). Com efeito, no cinema, a apreensão de um dado é imediata à imagem (ao menos em sua dimensão puramente visual, mas não interpretativa), ao passo que na literatura isso se dá de forma lenta, ao longo da decodificação e recepção, com o fluxo da escrita. A linguagem do cinema facilita, ao menos tecnicamente, a assimilação dos códigos superpostos, em função da sequência e velocidade destes, através do entrelaçamento visual das cenas, que anestesiam o esforço de apreensão por parte do espectador. Na literatura, estas se realizam de maneira também sequencial, mas sobre e "sob" a superfície da escritura, ao longo da narrativa. A literatura apela constantemente para a imaginação e o crescente, mas vagaroso interesse do leitor pelo fluxo da narrativa, o que faz dela uma modalidade artística inteiramente subjetiva, pois depende em considerável parte da atenção e capacidade de visualização durante a leitura. O cinema, por outro lado, apela para a visão e a emoção catártica, quase instantânea, produzida no espectador que, conduzido pela representação virtual de uma realidade, verossímil ou não, nela não interfere em nenhum momento com sua imaginação ou subjetividade pessoal, pois a história ou fato narrado em uma película é completamente independente do leitor-narrador que, após sua conclusão, sabe que a história se passou, enquanto fluxo narrativo, completamente exterior a ele e sua recepção, que foi, em tais termos, passiva. 
Um filme é composto do que há nele de ação, sequência, plano, diálogo, trilha sonora e silêncio, enquanto o texto literário se compõe do que nele houver de narração, descrição, cena ou diálogo, etc, sendo que tudo se passa, em termos de imagem, no nível interior da leitura, na tela mental do leitor. Desta forma, o cinema é uma realidade exterior ao espectador, um mundo cujas possibilidades esgotam-se em si mesmas, fechadas em si (em termos, é claro, do modo como as imagens se apresentam, prontas), enquanto a literatura é também uma realidade interior ao leitor, possível através da escrita, criadora e recriadora de um mundo cujas possibilidades estão sempre em aberto, uma vez que as modalidades de representação não estão necessariamente prontas e não são necessariamente as mesmas entre os leitores. Cada leitor/receptor executa, portanto, uma leitura e/ou recepção diversas ao nível da imaginação de outro leitor/receptor, não obstante o aparato da escrita. De acordo com Corseuil (2009, p. 374), o cinema, por sua vez, omite uma interpretação ou experiência subjetiva no desenlace das cenas, já que toda a representação do mundo exterior nele é instaurada e objetivada pelo olho eletrônico da câmera, enquanto a narração e a trama (enredo) dão-se através da seleção e edição de imagens.

Em cinema, é possível sugerir, todavia esta sugestão é feita de forma objetiva, através da imagem, pronta e irretocável, que é o que é, não aquilo que dela pode-se imaginar embora a questão da interpretação continue quase tão subjetiva quanto a literatura, sob determinados aspectos. Neste ponto, o cinema encontra seus vínculos históricos com sua arte irmã: o teatro. Em ambos, a ação e a imagem. Contudo, no cinema, o cenário, o tempo e o espaço não são fixos. As possibilidades se ampliam em relação ao teatro que, privado desta mobilidade, tem um leque menor de possibilidades expressivas e até mesmo sugestivas, ao menos quanto à imagem e à ação. Tanto em teatro como em cinema, no entanto, não há a figura do narrador permanente, como na literatura. No caso do cinema, a câmera supre este papel, pois ela se porta como o olho que tudo vê, mas nem tudo conhece, propiciando aos espectadores a sensação de serem "testemunhas oculares" de algo que acontece em uma realidade paralela, que lhes é alheia ou não pelo fato de poder presenciá-la. No teatro, a plateia também cumpre o papel de uma testemunha ocular das cenas. Na literatura, por sua vez, o narrador esforça-se para, de uma forma ou de outra, comunicar ao leitor o que se passa, fornecendo-lhes detalhes para vislumbrar o conjunto - ou não. Considerando que a literatura não tem mais a obrigação de seguir o modelo realista de narração, a apreensão do real pelo leitor através da narração torna-se periférica. 
Mas, neste caso, o roteiro constituiria um novo gênero literário? A resposta admite várias possibilidades, todas problemáticas. $\mathrm{O}$ roteiro, marcado desde o seu nascimento para ser esquecido, tem um uso temporário para a produção da obra audiovisual (o filme), assim como para o cinema enquanto meio artístico: presta-se somente para sinalizar, realizar a "marcação", oferecer a "rota", a direção a ser seguida pela equipe técnica de produção, diretores e atores. Uma vez concluído o filme, o roteiro não tem mais, aparentemente, utilidade prática para a película, pois todo o roteiro encontra-se nela performatizado, realizado, consumado. Não é um romance, pois carece do trabalho estético que lhe atribuiria densidade e sentido como narrativa literária, a menos que o trabalho estético sobre a escrita do roteiro seja de uma ordem mais artística que técnica, ou considerando que a técnica apresente um componente estético singular, e que o roteiro constitua, afinal, uma linguagem artística autônoma, um novo gênero literário. $\mathrm{O}$ roteiro seria, portanto, apenas um documento a mais para a história, e não um monumento artístico a ser venerado como realização estética, em toda a sua dimensão técnica? Se o filme é o próprio roteiro concretizado, por que no teatro o registro literário de uma peça tem importância? Considerando que não se pode performatizar e repetir, da mesma forma, duas vezes ou mais a mesma peça, nem eternamente com os mesmos atores, a performance final de um filme, mesmo a mais perfectível possível, é a garantia de que o roteiro tornou-se uma excrescência ao final da produção da obra audiovisual? Como no teatro é necessário que exista o texto da peça para que esta se reproduza, de forma similar ou diferente das anteriores, pois diferentes atores não interpretam da mesma forma o mesmo personagem, e a direção teatral tende a alterar a modalidade da representação, o roteiro seria, portanto, a garantia da possibilidade de refilmagem de um mesmo filme? Claro, aí estaríamos desconsiderando o filme como a performance ideal de um roteiro, e, deste modo, poderíamos ponderar sobre a necessidade de sempre adaptar as obras literárias à semântica, ao léxico e à ortografia da língua do tempo em que são lidas, e não do tempo em que foram produzidas. As obras literárias seriam sempre recriadas para serem relidas, assim como os filmes poderiam ser refilmados para serem vistos de novo. Neste caso, segundo Benjamin (1994), uma refilmagem condenaria o caráter aurático e estético do filme original, considerando a possibilidade de refazê-lo sob a ótica de uma nova produção. O fato é que o texto literário é lido pelos mais diferentes leitores, nas mais diferentes épocas, com as mais diversas recepções, mas é o mesmo, nunca se altera. O que altera é a sua recepção, a sua atualização diante dos mais diversos públicos, face às suas possibilidades expressivas. O cinema, uma vez realizado o filme, por sua vez, da mesma forma. Contudo, a problemática do roteiro como gênero intersemiótico/literário permanece, 
em especial considerando a questão da performance, por um lado, e da possibilidade de recriação, de outro.

A primeira questão que se abre, para uma possível definição de roteiro, é que antes de tudo um roteiro é uma história narrada/contada por meio de imagens, cenas, diálogos, descrições. A palavra, no roteiro, está a serviço da imagem e da ação, e não a serviço da narração escrita. No roteiro, a preocupação com a palavra é periférica, uma vez que a palavra deve se submeter às coerções daquilo que é visual, e não daquilo que é verbal. Associada a isso, a palavra deve estar submetida a uma estrutura dinâmica, que pressuponha sempre a ação, e não a digressão, o devaneio, o fluxo de consciência, a escrita subjetiva (a não ser nos diálogos e na narração em off), típicos da literatura ultramoderna e contemporânea. Com efeito, o roteiro possui uma especificidade em relação aos demais códigos de escrita, sobretudo literária, mesmo considerando o seu inevitável parentesco com a peça teatral escrita, da qual certamente absorveu quase todos os elementos de sua estrutura semiótica. Como o roteiro, entretanto, parte de um argumento inicial, em muitos casos semelhante à estrutura narrativa de um conto, alcançando na tradição europeia, às vezes, as dimensões de uma novela (um récit, no caso francês) ou mesmo de um romance, em que se acrescentam diálogos, descrição do drama, das cenas, de narração, é óbvio que o gênero nasce de um processo intersemiótico entre o texto narrativo e a peça teatral, com vistas à sua total transformação em imagem, trilha sonora, ação. Neste sentido, uma semelhança do roteiro com o romance é sua possibilidade de manipular a ficção, a fantasia, o verossímil, a imaginação, a sugestão, o suspense, ao longo da narrativa textual ou cênica.

Uma grande diferença, no entanto, reside na forma como o roteiro trabalha o espaço e o tempo ao longo de sua narrativa, uma vez que as possibilidades expressivas da narrativa fílmica permitem uma manipulação mais fidedigna, através da tecnologia e dos cenários, dos recursos espaciais e temporais necessários à consecução do projeto audiovisual. O roteiro permite ao leitor imaginar o texto como imagem, e, de um modo bem mais explícito que o texto literário, suscita uma visualização das possibilidades performáticas da representação humana, uma vez que toda a escrita debruça-se nesse sentido. O fato é que "o roteiro, ou melhor, o roteirista está muito mais perto do diretor, da imagem, do que do escritor"; ou, melhor ainda, "o roteiro é o princípio de um processo visual, e não o final de um processo literário" (COMPARATO, 1995, p. 20).

Como o roteiro não é a obra final, mas um gênero de escrita que permite a realização de uma obra, depois da qual se torna dispensável em relação à narrativa fílmica, é possível 
afirmar que a escrita do roteiro tem uma natureza puramente pragmática. Ao menos, em tese e em princípio, uma vez que as distinções entre um gênero de escrita e outro não são suficientes para negar que, tal como o romancista, o roteirista não ponha a escrita a serviço da narração, da trama e da descrição. As práticas não são necessariamente excludentes, pois a diferença reside mais nas finalidades, que essencialmente nos meios. Com a influência da narrativa fílmica sobre o universo dos leitores em todo o mundo, hoje é possível até falar de uma narrativa literária em que o primado da imagem talvez seja mais dominante que o exercício da digressão e do fluxo de consciência ao longo da narração, a exemplo - para ficarmos no território dos nomes mais evidentes e celebrados - de autores literários como Rubem Fonseca ou Patrícia Melo, no caso do Brasil, ou de autores de best sellers, como o caso de Dan Brown ou J. K. Rowling, cujos textos já nascem praticamente "roteirizados", aguardando suas respectivas versões para o cinema. Neste caso, estamos falando de uma possível literatura "intersemiótica", cujos elementos fabulativos já contemplam aqueles da "arte" do roteiro, impregnando a narrativa literária, que por sua vez se nutre de elementos fabulativos de origem fílmica. $\mathrm{O}$ fato é que isto talvez confirme a tese de que um bom texto, literário ou não, necessariamente tem um bom ou excelente potencial fílmico. Ou seja, o que está bem escrito pode ser um bom filme.

Considerando a tese do ut pictura poesis de Horácio, uma vez que a imagem esteve sempre entre os elementos necessários à composição dos textos literários, sobretudo aqueles destinados à rememoração de um grande número de leitores ou auditores - é bom lembrar que a épica homeriana, como todas as rapsódias, eram destinadas à leitura em voz alta para uma audiência ou plateia de iletrados -, é necessário evocar que a ênfase sobre a palavra enquanto elemento sígnico e estético particular à literatura é de origem historicamente recente. É a literatura moderna, e mais particularmente a lírica moderna, segundo Friedrich (1978), que desviou de vez a questão da mímesis como representação do "real" da natureza para a representação do "real" da ficção, suprimindo a necessidade dominante de um referente exterior completamente verossímil, até aboli-la quase por completo através de uma linguagem em que o referente natural desaparece para dar lugar a um referente de extração puramente linguística, composto mais de significante que de significado. A linguagem do texto literário moderno, em especial do texto poético moderno (Lautréamont, Baudelaire, Mallarmé, Rimbaud), aponta para um universo em que o imagético é composto de relações semânticas e sintáticas inusuais, de oximoros e de tensões dissonantes em relação à linguagem comunicativa, dobrando-se em uma linguagem autorreferente e, muitas vezes, incompreensível e hermética, uma vez que a 
lírica moderna aspirava à incomunicabilidade como projeto estético diante, talvez, das novas possibilidades de reprodutibilidade técnica da arte, como a fotografia, de acordo com Benja$\min (1994$, p. 176-177).

No terreno do comparatismo, a questão do roteiro como gênero intersemiótico ou mesmo intertextual, particularmente no caso de adaptação de obra literária à narrativa fílmica, assume uma importância capital para a compreensão das traduções ou transposições intersemióticas/transmidiáticas. A intermedialidade proposta como conceito-chave nos estudos de artes comparadas em língua alemã radica seu interesse, na proposta de Clüver (2006, p. 14), em uma perspectiva de cunho semiótico entre as artes e as mídias, conforme já mencionado, e supõe que a intertextualidade traz como consequência, em termos de suporte, a intermedialidade, ao menos em algum aspecto abrangido pelo conceito. $\mathrm{O}$ fenômeno não abrangeria, portanto, apenas textos literários ou verbais, mas incluiria todo um leque inaudito de obras, através das artes plásticas, música, dança, moda, entre outras, as quais concorrem no cinema para a realização na narrativa fílmica. Segundo Clüver, "sempre existe nos processos intertextuais de produção e recepção textual um componente intermidiático" (CLÜVER, 2006, p. 14), o que implica em dizer que o roteiro, como resultado intertextual, em diálogo com o texto de partida, ou texto-fonte, coloca como pressuposto, para a sua realização, não apenas $u m$ componente intermidiático (trilha sonora, sonosplatia, cenário, etc), mas vários, a fim de se obter a representação de aspectos sensorialmente apreensíveis da realidade exterior ou interior aos personagens, cujos dramas ou conflitos dramáticos têm que ser vividos em consonância com a coerência da mímesis da narrativa fílmica. Ainda conforme Clüver (2006, p. 15), o que importa enfatizar é que, ao longo do processo de construção ou de interpretação dos textos, há uma série de elementos textuais oriundos de diversas mídias, textos multimídias, "mixmídias" e intermídias, de modo que o horizonte de expectativa da recepção textual é constantemente fundado através de componentes extratextuais referidos no encadeamento lexical, semântico e sintático. O texto, portanto, bem como seu vasto repertório de referências, alude constantemente a elementos intersemióticos ou intermidiáticos, que partem de contextos compartilhados entre o autor e o leitor - ao menos, considerando as obras de agregação, nos termos de Antonio Candido (2000, p. 21). ${ }^{1}$

\footnotetext{
${ }^{1} \mathrm{Na}$ perspectiva de tais obras, a "experiência coletiva" fixa-se em recursos expressivos e/ou comunicativos decodificáveis, acessíveis, extraídos de um sistema simbólico dominante, aceito coletivamente e vigente em determinado contexto cultural de determinada época, em determinado país ou vários deles, a partir das formas expressivas conhecidas e consagradas em determinada sociedade ou várias delas. Contudo, não é possível desconsiderar aquelas obras de arte (as de segregação) que se preocupam em renovar o sistema simbólico e/ou os recursos expressivos de uma linguagem artística, voltando-se necessariamente a um público menor de receptores,
} 
Levando em consideração que a natureza de qualquer texto é, portanto, necessariamente intersemiótica, uma vez que todos os textos são compostos de signos verbais que aludem em grande parte a signos visuais - descontados os signos verbais que aludem a conceitos abstratos, não visíveis ou apreensíveis sensorialmente -, torna-se uma questão de ordem admitir que todo texto coloca-se numa fronteira de relações entre os sistemas sígnicos, e que, nesse sentido, a adoção da semiótica possui um considerável peso teórico na compreensão da estrutura sígnica que condiciona a performatização da imagem por meio da palavra, através do roteiro. Portanto, como gênero intersemiótico, o roteiro deve ser considerado antes de qualquer coisa o filme virtual, uma vez que o roteirista tem em seu campo de visão mental um conjunto de "imagens antevistas" (HOHLFELDT, 1984, p. 137). São estas imagens, primeiro concebidas virtualmente e depois roteirizadas, que deverão possibilitar ao diretor e à equipe de produção técnica da película a armação (estrutura) em forma de esqueleto ou escaletta, de modo a permitir que um conjunto de cenas seja visualizado e, posteriormente, filmado e combinado através da montagem, dando consecução à obra audiovisual que é o próprio filme. Neste sentido, o roteiro pode ser comparado a outros sistemas sígnicos utilizados para obras que devem ser performatizadas fora do registro escrito, como a partitura musical. Conforme Hohlfeldt, (1984, p. 137), como o roteiro, a partitura musical não é a obra à qual se destina, que se torna visível (no caso da partitura, audível) apenas a partir do momento em que a orquestra, conduzida pelo maestro, ou o instrumentista (conduzido pelo sistema sígnico de notas musicais), interpretam a música em potencial ali registrada e contida.

Como a palavra aqui está subordinada às coerções da imagem e do som, uma vez que o roteiro esforça-se, de modo sistemático, organizado e estruturado, em prever cada imagem e/ou cena de um filme que ainda não se realizou, de acordo com as tecnologias disponíveis e/ou possíveis de serem criadas para a sua performatização, seu conteúdo, em forma de manuscrito, é uma descrição pormenorizada de todas as ações, diálogos, sons, trilha musical ou sonora, problemas artísticos e técnicos previstos, os quais uma equipe de profissionais especializados realizará ou resolverá. Portanto, o roteiro e a peça de teatro aproximam-se muito nesses aspectos, uma vez que aquela também apresenta a indicação de todos os detalhes mínimos necessários à montagem do espetáculo teatral. Não necessariamente todos, é evidente, uma vez que, a cada montagem, leituras e releituras do mesmo texto podem conduzir a uma nova interpretação cênica. De qualquer modo, a representação dos atores em combinação com os

alheios ao horizonte de expectativa e/ou gosto dominantes de suas respectivas sociedades e época (CANDIDO, 2001, p. 21). O cinema também as possui entre suas produções. 
componentes dramáticos (cenário, sonosplatia, vestuário, etc) variam de montagem para montagem, impossibilitando uma completa padronização do mesmo texto em termos de performance. A mesma questão verifica-se quanto à performance das partituras musicais. Algumas filigranas interpretativas são notáveis e mesmo gritantes de uma orquestra para outra, uma vez que as diferenças de virtuosismo e competência técnica (somados ao talento) do maestro, instrumentistas, coro e solistas, são suficientes para que uma mesma partitura musical conheça versões bastante distintas, a ponto de alterarem consideravelmente a qualidade e mesmo as possíveis intenções originais do compositor da música. As diferenças notadas em refilmagens de películas clássicas também apontam para a mesma direção. Tais diferenças chamam atenção para um fato inescapável: as interpretações, as distintas performances, podem ser classificadas como leituras particulares de um mesmo texto, somadas às coerções das condições técnicas para a sua realização. Somente a técnica do enquadramento, em termos fílmicos, já seria o suficiente para desautorizar qualquer possibilidade de se ventilar que uma película é a performance ideal ou perfeita de um determinado roteiro, uma vez que grandes produções podem se valer do expediente de filmar a mesma cena sob vários ângulos e perspectivas distintas, com várias câmeras dispostas em pontos diversos, a fim de que a edição final possa selecionar uma delas. A escolha de ângulos, os cortes, as modificações, a ordem das cenas, a própria montagem, são, portanto, elementos de subjetividade e seleção presentes ao longo de toda a narrativa fílmica, e a escolha de um deles em detrimento de outro determina o grau das intenções do realizador cinematográfico, bem como o quanto o filme se afasta ou não do roteiro. De qualquer modo, em tais termos, mesmo levando em consideração um elevado grau de cultura cinematográfica, nota-se o quanto a palavra não é o veículo mais adequado para a transmissão da imagem de um emissor a um receptor, e como a interpretação pode conduzir mais a um véu denso de sentidos possíveis do que a um sentido unívoco, o que não constitui ainda um interdito para o roteiro como gênero intersemiótico.

Como se vê, entretanto, a partir das considerações realizadas até o momento, as possíveis abordagens entre os diversos sistemas artísticos, dentro dos estudos comparados, estabelece-se no campo difícil e por vezes polêmico das "relações intersemióticas" (GONÇALVES apud MARTINEZ, 2002, p. 7). Não poderia ser de outra forma, uma vez que o advento das ciências da linguagem, desde o final do século XIX, trouxe à baila a consciência de que a linguagem, e seus respectivos fenômenos de significação e interpretação, constitui um excelente objeto de investigação lógica, preocupação que se tornou cada vez mais acentuada à medida que progride o avanço da semiótica como ciência da linguagem. Contudo, a necessi- 
dade de estabelecer comparações, aproximações e estudos entre objetos artísticos pertencentes a sistemas sígnicos diferentes deve ser conduzida com prudência, uma vez que cada sistema propicia uma rede peculiar de metáforas, significados, intenções, em geral não completamente abarcáveis por uma mera aproximação. Cada sistema artístico possui, em sua própria especificidade, um sistema sígnico próprio, com uma natureza estética distinta dos demais, o que permite, de um lado, separações, e de outro, aproximações. Nesse sentido, é possível supor que, na área dos estudos interartes, a existência de uma rede de relações analógicas e de relações homológicas, que permita o estabelecimento de um método comparativo apoiado, portanto, em semelhanças e distinções. As relações analógicas, assim, permitiriam uma primeira abordagem, um levantamento inicial das semelhanças mais imediatas, uma vez que se encontrariam em estruturas superficiais de contiguidade e/ou proximidade, possibilitando pontos de contato primários, denominados a priori de "pontos de partida" (GONÇALVES apud MARTINEZ, 2002, p. 7). Já as relações homológicas correspondem a estruturas profundas de contiguidade e/ou proximidade, constituindo assim os denominados, a priori, de "pontos de chegada":

\begin{abstract}
... Muitas vezes, o que atrai em formas diferentes de arte, levando-nos a aproximálas em busca de seus elementos mais internos, são aspectos de natureza analógica, traços evidentes de similaridades que nos instigam para uma perscrutação a respeito de suas estruturas. Entretanto, esses aspectos, repetindo, servem apenas como pontos de partida e não como pontos de chegada, nos estudos mais apurados das artes comparadas. Tornam-se, por exemplo, completamente infrutíferas as relações analógicas de natureza temática: estudos que buscam a aproximação de um determinado tema manifestado em sistemas artísticos diferentes (pintura e literatura/música e artes plásticas) ou até mesmo no mesmo sistema (literatura e literatura). Trata-se de "conferir" a obviedade por meio de um caminho previamente determinado pela própria arte. Uma vez que essas aproximações já nos são dadas antes mesmo de qualquer estudo, tornam-se desnecessárias. Quase da mesma forma, são estéreis as relações analógicas que se colocam como pontos de chegada nas aproximações de estilos de época entre sistemas diferentes (GONÇALVES apud MARTINEZ, 2007, p. $7-8)$.
\end{abstract}

Do ponto de vista das relações analógicas, são mais que notórias e evidentes as semelhanças entre a narrativa do roteiro e a narrativa dramatúrgica e/ou literária. Aspectos relativos ao tema, ao personagem, ao conflito dramático, à intriga, ao enredo, ao estilo, são pontos de contato ululantes e fazem parte do repertório expressivo de ambos os meios artísticos. Essas primeiras semelhanças, entretanto, não autorizam uma aproximação comparativa entre ambos os meios, uma vez que as particularidades de cada meio não emergem a partir das relações analógicas, pura e simplesmente, mas das relações homológicas. Seria necessário, portanto, aprofundar a relação intesemiótica, mergulhando na homologia possível entre os meios 
expressivos, a fim de detectar as semelhanças estruturais e de origem, contidas ao longo das estruturas dos sistemas artísticos distintos. Toma-se, desse modo, a evidente analogia do início, com vistas a detectar a estrutura semiótica profunda de cada linguagem artística (literatura e roteiro), a fim de alcançar a relação homológica entre as diferentes obras, analisando por fim os recursos artísticos que cada uma possui para a realização do mesmo objetivo (tema, assunto, estilo, narrativa, personagem, etc). Desta forma, superando as semelhanças iniciais que se detectam no nível das estruturas analógicas, tomadas como meros pontos de partida, e aprofundando a análise nas estruturas homológicas, os estudos interartes podem superar, no caso do roteiro e da transposição intersemiótica de obras literárias para a narrativa fílmica, o estatuto de simples “curiosidade estética" (GONÇALVES apud MARTINEZ, 2002, p. 8), preocupada apenas em catalogar o rol de semelhanças e diferenças entre as obras, a fim de quantificar ou qualificar o grau de fidegnidade da adaptação de obras literárias à versão cinematográfica, o que se revela, como estudo lógico, como um esforço condenado a ser improfícuo e inútil. Semelhanças e analogias iniciais não são resultados finais.

De igual forma, considerar ou não o roteiro como gênero pertencente à literatura depende de uma série de fatores que talvez tenham pouco a ver com a arte cinematográfica propriamente dita. A primeira questão tem mais a ver com forma (a escrita como meio expressivo), e, neste caso, o roteiro estaria a meio caminho entre a narrativa literária e a narrativa fílmica, como gênero intersemiótico que é. A segunda questão teria a ver com o valor estético, com a dimensão monumental do texto. Evidentemente, nem todos os textos escritos com pretensão literária são necessariamente bons, embora sejam considerados como pertencentes ao domínio artístico literário. Assim como nem toda ficção entra para o cânone das obras literárias como arte, nem todos os roteiros necessariamente têm que ser considerados artísticos simplesmente porque pertencem ao domínio artístico cinematográfico. A recíproca é verdadeira: nem todos os filmes produzidos entram necessariamente para o cânone de obras cinematográficas consideradas realmente artísticas. Essas considerações e reflexões reduzem muito o âmbito da polêmica do roteiro como gênero literário ou não, ainda que seu caráter seja intersemiótico.

De qualquer modo, como qualquer peça de teatro é virtualmente um roteiro, menos as indicações técnicas indicadas à margem ou nas rubricas, é possível também considerar o contrário, que todo roteiro é virtualmente uma peça teatral, levando em conta a necessidade de adaptação às coerções específicas do meio artístico para o qual se traduz a peça ou o roteiro. As diferenças entre os respectivos sistemas artísticos, assim como as aproximações entre as 
suas linguagens específicas, permite sempre supor que surgirão semelhanças, dificuldades e distinções ao longo da conformação de seus procedimentos formais, que ocorrem sempre ecfrasticamente, como uma recriação dos recursos expressivos do texto de partida através das possibilidades expressivas do texto de chegada, através do processo de reescrita (ekphrasis) do texto original, conforme já mencionado anteriormente. Assim como o tradutor, ao adaptar uma obra literária para os recursos expressivos da linguagem fílmica, o roteirista estabelece uma tentativa de recriação e reescrita dos procedimentos formais do texto "traduzido". Contudo, é necessário sempre relembrar que uma considerável parcela dos recursos expressivos próprios da literatura terão que ser abandonados em nome das particularidades próprias dos recursos expressivos do cinema, uma vez que os recursos expressivos do sistema artístico de origem são diferentes dos de chegada. Desta forma, o esforço interpretativo do roteirista só pode ser mensurado através da fidedignidade ao texto de origem se, com efeito, acontecer o "transporte" ou "transposição" de seus recursos expressivos, e isso só é possível naqueles textos "literários' que já nascem "roteirizados", criados para serem vertidos à linguagem fílmica. De um lado ou de outro, não ocorre propriamente a "tradução".

Walter Benjamin, em seu célebre texto "A obra de arte na era de sua reprodutibilidade técnica", afirma que as novas tecnologias são responsáveis por saltos qualitativos na história do cinema, cujas origens remontam ao cinema mudo, que entrou em crise e recobrou sua vitalidade com o advento da tecnologia do cinema falado, depois do cinema em cores, posteriormente da avançada tecnologia de efeitos visuais, levando as massas, sempre sequiosas de inovações técnicas ao longo da modernidade, a novamente frequentar as salas de exibição (1994, p. 172). O fato é que as novas tecnologias alteram profundamente a amplitude dos recursos expressivos do cinema, transformando de modo considerável a especificidade do roteiro como gênero intersemiótico, uma vez que, desde o início da história cinematográfica, não era suficiente ao roteirista apenas conceber o texto do roteiro como uma simples narrativa em forma de cenas e diálogos: era necessário, para além disso, concebê-lo sempre em face das novas possibilidades técnicas, cujas consequências eram sempre o incremento do potencial expressivo do cinema. Como o cinema é a arte que, segundo Benjamin, atinge o nível mais elevado de perfectibilidade entre as demais artes (BENJAMIN, 1994, p. 173), em razão do grau de perfeição técnica que somente ele pode atingir na consecução de um projeto audivisual através do roteiro, o próprio roteiro torna-se uma forma de escrita de caráter volátil, em permanente transformação, que tende a receber o maior número possível de contribuições de coautoria, uma vez que um único roteirista pode não dar conta de todo o processo criativo da 
arte cinematográfica. Assim, o grau de perfeição técnica do roteiro é atingido após uma primeira "demão" do autor da ideia, que por sua vez submete-o à equipe técnica de produção, a qual lhe acrescentará novos elementos de caráter audiovisual, inserindo-o cada vez mais na fronteira intersemiótica entre a arte cinematográfica e a arte literária.

A performance cinematográfica pressupõe, assim, uma série de etapas, que têm que ser vencidas antes de realizado o filme propriamente dito. Dessa forma, considerar o roteiro como gênero literário, tendo em vista a advertência de Benjamin (1994, p. 177), é também um pouco considerar a reprodução de ações e objetos, ao longo da película, como verdadeiras obras de arte, o que não é o caso, pois toda obra é, necessariamente, composta de fragmentos não artísticos ao longo de sua composição. O cinema não é o registro de um momento único, que não poderá mais ser repetido, mas o registro de uma performance desejada pela equipe de produção, que parte da cena, imagem ou situação ideal, descrita tecnicamente através do roteiro, e vai ao encalço de sua realização técnica. Portanto, uma cena isolada e deslocada do conjunto de cenas da película não pode ser considerada como uma obra de arte, da mesma forma que uma frase banal, corriqueira, como "vou ao supermercado", não pode ser considerada um texto literário. Assim como a obra de arte literária é formada pelo acervo narrativo que a compõe (frases, cenas, diálogos, descrições, digressões, fluxo de consciência, etc), e não por um dos elementos expressivos isolado e descontextualizado do conjunto, o cinema só pode ser concebido como arte através da montagem final, pois "cada fragmento é a reprodução de um acontecimento que nem constitui em si uma obra de arte, nem engendra uma obra de arte, ao ser filmado" (BENJAMIN, 1994, p. 178). Através da montagem, procede-se à seleção das várias versões possíveis de uma mesma cena, uma vez que processo de produção cinematográfica é similar, nos termos de Benjamin, ao desempenho de atletas em uma competição esportiva, na qual se avalia a performance de cada um, até declarar-se qual deles executou a melhor, obtendo um recorde de preferência. Desse modo, partindo do parâmetro estabelecido em roteiro, a equipe de produção, capitaneada pelo diretor e depois pelo montador (que podem ser a mesma pessoa), arbitra sobre qual das várias performances de uma mesma cena, gravada várias vezes em forma de teste, é a melhor para atingir o grau de perfectibilidade ambicionado pelo roteiro. A cena em particular, entretanto, não tem nenhuma funcionalidade artística a priori, se não garante a eficácia artística e/ou comercial do conjunto filme em questão, o que reduz muito a pretensão de qualquer roteirista a ambições literárias de longo alcance. Devido, portanto, a tal especificidade, o roteiro não consegue força de empuxo necessária para escapar da gravidade de meio expressivo próprio, que é o cinema, ficando a meio cami- 
nho entre a arte cinematográfica e a arte literária, em grande parte dos casos, pois sua natureza e o seu domínio específicos não são o da palavra, tampouco da escrita como arte, mas sim o da imagem e de uma performance específica como arte, sem as quais não pode obter o filme. Assim, o leitor de roteiro tem que ter sempre em vista a sua eficácia como imagem, som e performance, para muito além da palavra. Ele tem que o enxergar o "filme" em sua tela mental, a todo o momento, e isso só é possível de se obter através de uma educação cinematográfica longa e específica, e não apenas literária, a qual exige uma forma de representação de natureza muito diversa e bastante específica. Sem palavras, o cinema é possível. Apenas com imagens, não há literatura. Cinema e literatura partilham de semelhanças, mas não em nível de código.

\section{Considerações finais}

Por último, vale lembrar que grande parte dos trabalhos dedicados à análise da tradução intersemiótica entre filmes e livros desconsidera amplamente o roteiro como gênero de escrita intermediário, intersemiótico por natureza, e que um livro, sobretudo o literário, solicita que seja realizado, sobre a superfície de sua linguagem e recursos expressivos, um processo de découpage (recorte). Tal processo consiste em suprimir justamente todos os recursos expressivos da literatura que não sejam possíveis de serem transformados em imagens, sons, performances, de tal modo que toda uma literatura baseada somente no fluxo de consciência, ou trechos inteiros de "romances" cujas características estejam apoiadas nessa modalidade narrativa, são totalmente "apagados" quando roteirizados, devido à impossibilidade da linguagem cinematográfica de representá-los visualmente. A especificidade da linguagem da literatura permite uma modulação expressiva de determinados recursos artísticos que somente são obtidos através da palavra escrita, e que no roteiro tornam-se dispensáveis, pois o roteiro não é domínio especificamente verbal, mas um trânsito do verbal para o visual e o sonoro. Desse modo, os trabalhos que ignoram ou desprezam o roteiro no processo de transposição intersemiótica impossibitam a análise de penetrar mais profundamente nas etapas de reescrita ecfrástica, diminuindo consideravelmente o alcance dos resultados obtidos. A não ser nos livros obviamente "roteirizados", filmes adaptados a partir de obras literárias são o resultado de um esforço enorme de "transposição". E esse esforço só pode ser dimensionado em sua totalidade a partir da análise do roteiro e seu processo de recriação. 


\section{Referências}

\section{ADORNO et ali. Teoria da cultura de massa. São Paulo: Paz e Terra, 2000.}

ARISTÓTELES; HORÁCIO; LONGINO. A poética clássica. São Paulo: Cultrix, 1990.

BENJAMIN, Walter. A obra de arte na era de sua reprodutibilidade técnica (primeira versão). In: Magia e técnica, arte e política: ensaios sobre literatura e história da cultura. Tradução de Sérgio P. Rouanet. 7. ed. São Paulo: Brasiliense, 1994.

BAUDELAIRE, Charles. As flores do mal. Rio de Janeiro: Nova Fronteira, 1985.

CANDIDO, Antonio. Literatura e sociedade. São Paulo: T. A. Queiroz; Publifolha, 2000.

CLÜVER, Claus. Inter textus/inter artes/inter media. Aletria: revista de estudos de literatura, Belo Horizonte, Vol. 6, n. 14, p. 11-41, jul./dez. 2006.

Estudos interartes - conceitos, termos, objetivos. Literatura e sociedade - Revista de teoria literária e literatura comparada, São Paulo, n. 2, p. 37-55,1997.

COMPARATO, Doc. Da criação ao roteiro. Rio de Janeiro: Artemídia Rocco, 1995.

CORSEUIL, Anelise Reich. Literatura e cinema. In: BONNICI, Thomas; ZOLIN, Lúcia Osana. Teoria literária: abordagens históricas e tendências contemporâneas. 3. ed. rev. e amp. Maringá: EDUEM, 2009.

FRIEDRICH, Hugo. Estrutura da lírica moderna: da metade do séc. XIX a meados do século XX. Trad. de Marise M. Curioni e Dora F. da Silva. São Paulo: ed. Livraria Duas Cidades, 1978.

GONÇALVES, A. J. Relações intersemióticas: alguns fundamentos. Palestra proferida no curso de Letras da Unesp, São José do Rio Preto, abr. 1994. Passim.

Laokoon revisitado: relações homológicas entre texto e imagem. São Paulo: Edusp, 1994. (Texto e Arte, n. 7).

MARTINEZ, Cristiano Monteiro. Memórias do cárcere: do texto literário à leitura cinematográfica. Dissertação de mestrado. Curitiba: Universidade Federal do Paraná, 2002 (mimeo).

HOHLFELDT, Antonio. Cinema e literatura: liberdade ambígua. In: AVERBUCK, L. (Org.). Literatura em tempo de cultura de massa. São Paulo: Nobel, 1984.

HOHLFELDT, Antonio; MARTINO, Luiz C.; FRANÇA, Vera Veiga. Teorias da comunicação: conceitos, escolas e tendências. Petrópolis: Vozes, 2001.

[Recebido em janeiro de 2012 e aceito para publicação em junho de 2012]

Cine and literatura: some reflections and comments about the script as a intersemiotic gender

Abstract: This work aims to perform some analysis and considerations regarding the aesthetic and structural intersections, inter-semiotic point of view, between the script and literature, to develop a theory of script as intersemiotic gender. Based on the concepts of transposition intersemiotic, ecfrasis, intertextuality and inter-midiality, especially from the Clüver Claus's reflections, it is intended in this paper to demonstrate the importance of the script for the realization of intercommunication between cinema and literature, is to analyze the boundaries between verbal art and visual media. 
Keywords: Literature. Cinema. Script. Intersemiotic transposition.

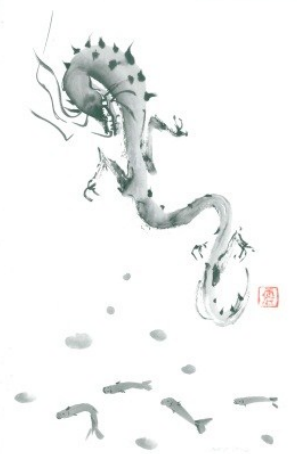

